\title{
Have whales returned to a historical hotspot of industrial whaling? The pattern of southern right whale Eubalaena australis recovery at South Georgia
}

\author{
Jennifer A. Jackson ${ }^{1, *}$, Amy Kennedy ${ }^{2}$, Michael Moore ${ }^{3}$, Artur Andriolo ${ }^{4,5}$, \\ Connor C. G. Bamford ${ }^{1,6}$, Susannah Calderan ${ }^{7}$, Ted Cheeseman ${ }^{8,9}$, George Gittins ${ }^{10}$, \\ Karina Groch ${ }^{11}$, Natalie Kelly ${ }^{12}$, Russell Leaper ${ }^{13}$, Matthew S. Leslie ${ }^{14}$, \\ Sarah Lurcock ${ }^{15}$, Brian S. Miller ${ }^{12}$, Jessica Richardson ${ }^{16}$, Vicky Rowntree ${ }^{17,18}$, \\ Patrick Smith ${ }^{10}$, Emilie Stepien ${ }^{19}$, Gabriele Stowasser ${ }^{1}$, Phil Trathan ${ }^{1}$, Els Vermeulen ${ }^{20}$, \\ Alexandre N. Zerbini ${ }^{2,5,21,22,23}$, Emma L. Carroll ${ }^{24,25}$ \\ ${ }^{1}$ British Antarctic Survey, High Cross, Cambridge CB3 0ET, UK
}

For a full list of affiliations see Supplement 1 at www.int-res.com/articles/suppl/n043p323_supp1.pdf

\begin{abstract}
Around 176500 whales were killed in the sub-Antarctic waters off South Georgia (South Atlantic) between 1904 and 1965. In recent decades, whales have once again become summer visitors, with the southern right whale (SRW) the most commonly reported species until 2011. Here, we assess the distribution, temporal pattern, health status and likely prey of SRWs in these waters, combining observations from a summertime vessel-based expedition to South Georgia, stable isotope data collected from SRWs and putative prey and sightings reports collated by the South Georgia Museum. The expedition used directional acoustics and visual surveys to localise whales and collected skin biopsies and photo-IDs. During $76 \mathrm{~h}$ of visual observation effort over 19 expedition days, SRWs were encountered 15 times ( 31 individuals). Photo-IDs, combined with publicly contributed images from commercial vessels, were reconciled and quality-controlled to form a catalogue of 6 fully (i.e. both sides) identified SRWs and 26 SRWs identified by either left or right sides. No photo-ID matches were found with lower-latitude calving grounds, but 3 whales had gull lesions supporting a direct link with Península Valdés, Argentina. The isotopic position of SRWs in the South Georgia food web suggests feeding on a combination of copepod and krill species. Opportunistic reports of SRW sightings and associated group sizes remain steady over time, while humpback whales provide a strong contrast, with increased sighting rates and group sizes seen since 2013. These data suggest a plateau in SRWs and an increasing humpback whale presence in South Georgia waters following the cessation of whaling.
\end{abstract}

KEY WORDS: Eubalaena australis $\cdot$ Whale $\cdot$ Whaling $\cdot$ Antarctic $\cdot$ Recovery $\cdot$ Habitat use

\section{INTRODUCTION}

The sub-Antarctic island of South Georgia lies in the high latitudes of the South Atlantic, just south of the Polar Front and within the Antarctic Zone of the Antarctic Circumpolar Current (Fig. 1). To the east of the island, the front of the Southern Antarctic Circum-

${ }^{*}$ Corresponding author: jeck@bas.ac.uk polar Current is deflected northwards, creating a mixing zone of water masses offshore to the north and east of South Georgia. The shelf waters around the island are characterised by very high productivity of phytoplankton and copepods and are globally recognised as a biodiversity hotspot (Hogg et al. 2011) containing a very large biomass of Antarctic krill

(C) The authors and the British Antarctic Survey 2020. Open Access under Creative Commons by Attribution Licence. Use, distribution and reproduction are unrestricted. Authors and original publication must be credited.

Publisher: Inter-Research · www.int-res.com 


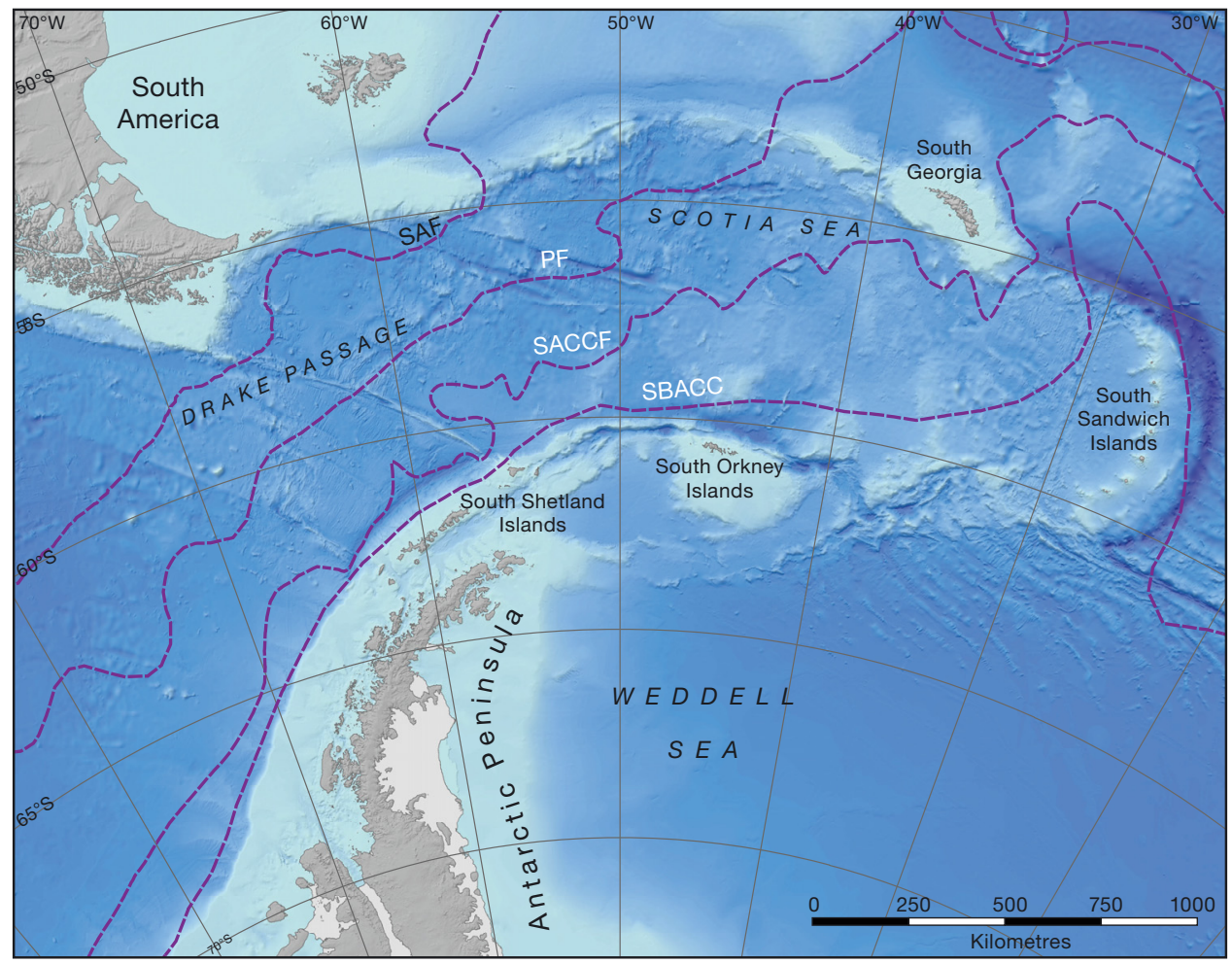

Fig. 1. Oceanographic and South Atlantic context of South Georgia. Dashed purple lines: oceanic fronts. SAF: Sub-Antarctic Front; PF: Polar Front; SACCF: Southern Antarctic Circumpolar Front; SBACC: Southern Boundary Antarctic Circumpolar Current

Euphausia superba and other zooplankton (Atkinson et al. 2001). A variety of species feed on krill in this ecosystem, including seals, cetaceans, seabirds and fish (Trathan \& Croxall 2004, Murphy et al. 2007). As early as 1775, when Captain James Cook first landed on the island, whales were anecdotally reported to be abundant near South Georgia. During the subsequent century, South Georgia was the site of significant sealing activity (Headland 1989, Hoffman et al. 2011). It was not, however, until the $20^{\text {th }}$ century that South Georgia became the epicentre of modern whaling in the Southern Hemisphere, with 176500 whales killed within a day's transit from the coast (Allison 2013; Fig. 2, Table 1). The shore-based whaling stations closed in the 1960s and a moratorium on whaling from factory ships for all species other than minke whales was agreed by the International Whaling Commission (IWC) in 1979. Since then, 2 dedicated investigations into summer cetacean abundance in South Georgia waters have been carried out: a line transect survey in 1997 out to the $2000 \mathrm{~m}$ isobath along the north coast (Moore et al. 1999) and a research cruise by Brazilian investigators in 2006 (RossiSantos et al. 2007). Cetacean observations were also made on other South Georgia expeditions, for exam- ple during dedicated krill surveys (Reid et al. 2000, Hedley et al. 2001, Reilly et al. 2004, Širović et al. 2006, Tarling et al. 2012) and as part of a cetacean and seabird survey along the north Scotia Ridge (Joiris et al. 2015). Most other sightings of whales in South Georgia come from opportunistic sources (tourist, fishery and land-based sightings; Moore et al. 1999, Richardson et al. 2012).

Taken together, the opportunistic sightings and survey data assembled to date suggest that the southern right whale Eubalaena australis (SRW) was the most commonly sighted whale in nearshore waters off South Georgia up to 2011 (Moore et al. 1999, Richardson et al. 2012). As with some other baleen whale species, SRWs show a seasonal pattern of summering in high latitude offshore feeding grounds and migrating to mid-latitude coastal wintering grounds in autumn, where mating and calving occurs. In the southwest Atlantic, wintering grounds for SRWs are found along the coast of Argentina, Uruguay and southern Brazil (see Harcourt et al. 2019 for a recent review). There, SRWs were a relatively easy target for small boat coastal whaling because they congregate to give birth and nurse their calves in calm sheltered waters, are slow swimmers and float when dead (IWC 2001). 


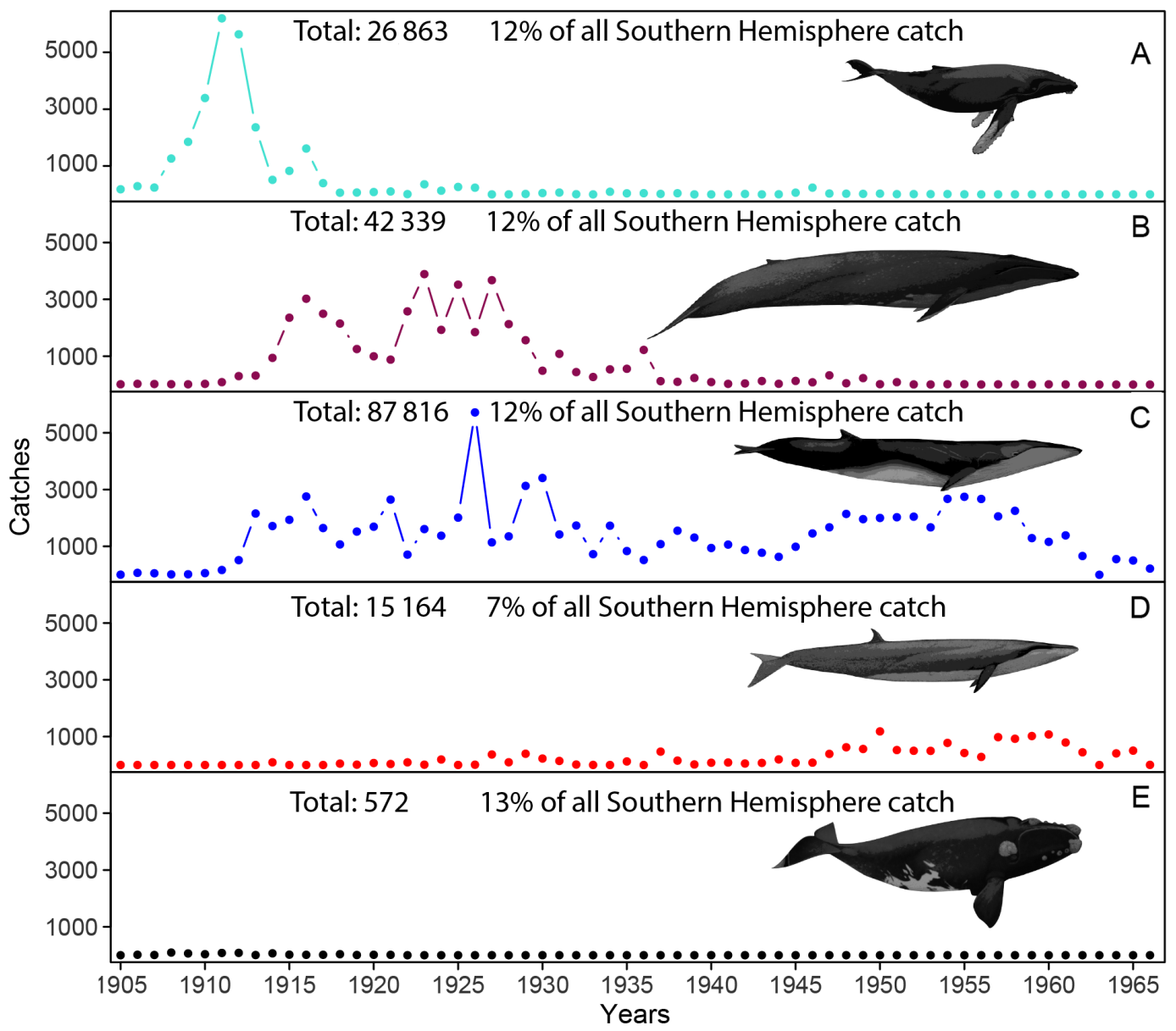

Fig. 2. South Georgia baleen whale catches between 1904 and 1966: (A) humpback whales, (B) blue whales, (C) fin whales, (D) sei whales, (E) southern right whales

Table 1. Total catches of whales in South Georgia waters between 1905 and 1965 (IWC catch database 5.5)

\begin{tabular}{|lr|}
\hline Species & Totals \\
\hline Blue & 42339 \\
Fin & 87816 \\
Sperm & 3734 \\
Humpback & 26863 \\
Sei & 15164 \\
Right & 572 \\
Unspecified & 43 \\
Total & 176532 \\
\hline
\end{tabular}

Hunting licences were first issued for the Brazilian SRW wintering grounds in the early 1600s by charter of King Philip III of Spain (Hart \& Edmundson 2017). This represented a substantial portion of the SRW southwest Atlantic wintering range, which currently spans between Bahia State in Brazil at $12^{\circ} \mathrm{S}$ (de Morais et al. 2017) and Golfo San Jorge in Argentina at $46^{\circ} \mathrm{S}$ (Iñiguez et al. 2003). The Brazilian fishery was a Basque whaling style operation that lasted until the 1820s (Reeves \& Smith 2006, de Morais et al. 2017). Such shore-based whaling stations were usurped as the primary whaling industry by pelagic North American and British whalers operating in the $18^{\text {th }}$ and $19^{\text {th }}$ centuries (Townsend 1935, Tønnessen \& Johnsen 1982, IWC 2001, Smith et al. 2012). By the $20^{\text {th }}$ century era of modern whaling, SRWs were already depleted by this long history of whaling and likely to have been in low abundance across the southwest Atlantic. In South Georgia, SRWs were only rarely caught, with only 572 catches reported during whaling operations around South Georgia between 1904 and 1965 (Allison 2013). Right whaling was officially banned in 1937. However, illegal Soviet whaling in offshore areas of the southwest Atlantic killed a further 1356 SRWs between 1960 and 1971 (Tormosov et al. 1998). While $20^{\text {th }}$ century SRW catches were very low compared to the catches of other baleen whales in South Georgia waters, they reflected the fact that SRWs had been hunted for much longer than the other baleen 
whale species and were already significantly depleted by the time whaling began at South Georgia.

Today, the SRW population in the southwest Atlantic is slowly recovering (with the Argentine calving ground estimated at $\sim 4000$ whales in 2010 ; IWC 2013). Whales are now regularly seen in bays along the coast of Argentina and southern Brazil during winter and spring. Pioneering photo-ID work, based on the unique pattern of callosities on the head of each whale, has enabled identification of individual right whales and the tracking of their activities through time (Payne et al. 1983, Kraus et al. 1986). These photo-ID studies began in Península Valdés, Argentina, in the 1970s and in Brazil in the 1980s (Payne 1986, Groch et al. 2005). The summer foraging destinations of whales wintering in Península Valdés have been investigated using photo-ID, stable isotope and satellite telemetry data, and directly link this calving ground to South Georgia (Best et al. 1993, Moore et al. 1999, Rowntree et al. 2001, Valenzuela et al. 2009, 2018, Zerbini et al. 2018). The stable isotope work led to the hypothesis that whales in the southwest Atlantic use 2 primary offshore feeding strategies during summer: one where they feed on copepods in lower latitude waters of the South Atlantic, including the Patagonian shelf, and another where they feed on Antarctic krill in the high latitudes of the South Atlantic, including South Georgia, the Scotia Arc and the South Sandwich Islands (Valenzuela et al. 2009, 2018). Feeding habitat quality is thought to affect SRW population dynamics by mediating prey availability. High latitude climate anomalies (e.g. mediated by El Niño and the Southern Annular Mode) impact South Atlantic krill distribution and density (Murphy et al. 2007) and lead to variations in climate and krill densities that have been associated with reduced calving success (Leaper et al. 2006, Seyboth et al. 2016), suggesting that the feeding conditions at high latitudes affect calving success. Whether the overall signal of calving success within the population holds for lower latitude feeders or whales using a mixed strategy is unclear.

The 1997 whale research expedition to South Georgia concluded that $18 \mathrm{yr}$ after the end of commercial whaling at South Georgia, there was no evidence of major concentrations of whales returning to the island (Moore et al. 1999). Twenty-one years later, we conducted a new expedition to South Georgia waters, spanning the expected period of peak SRW occurrence in summer months (January-February 2018). This expedition was designed to investigate SRW genetic diversity, population connectivity with calving areas, health status, prey sources, acoustic behaviour and habitat use in relation to the krill fishing within the sustainable-use South Georgia and South Sandwich Islands Marine Protected Area. Here, we report the first results of this survey, and consider our findings in the context of past catches, recent sightings and the environmental context of whales feeding in the vicinity of South Georgia.

\section{MATERIALS AND METHODS}

Our area of focus in this study was the South Georgia marine ecosystem, spanning the coastal and shelf waters around South Georgia and the shelf waters of Shag Rocks to the west of the island $\left(33.5^{\circ}-43^{\circ} \mathrm{W}, 53^{\circ}-56^{\circ} \mathrm{S}\right.$; Fig. 1$)$. The voyage was conducted on the R/V 'Song of the Whale' (owned and managed by Marine Conservation Research $\mathbf{1}$ ), which departed from the Falkland Islands (Islas Malvinas) on Monday 22 January 2018. The vessel sailed to the north coast of South Georgia, where she remained for $19 \mathrm{~d}$ (28 January to 16 February 2018) before returning to the Falkland Islands (Islas Malvinas) on Wednesday 21 February (a total of 31 d sailing). There were 8 researchers and 3 crew members onboard. All data collection was carried out under permit RAP/2017/017 issued by the Government of South Georgia and the South Sandwich Islands (GSGSSI) following review and approval of all data collection approaches by the British Antarctic Survey (BAS) Animal Welfare and Ethics Review Board (review \#1040).

\subsection{Survey effort and image collection}

Visual sightings were conducted by the research team, with multiple categories of visual effort based on both sighting conditions and the type of survey being conducted. For much of the time around South Georgia, the vessel track was chosen based on acoustic SRW detections (see Section 2.2). Thus, visual searching effort was based on some prior knowledge of SRW locations. This effort was categorised as 'acoustic bearing'. If no recent information on SRW location was available, effort was classified as 'random searching', with search locations chosen based on assessment of weather conditions and the pattern

1 https://www.marineconservationresearch.co.uk 
of prior sightings. With both effort types, visual observations were carried out during daylight hours when the boat was underway, and when conditions allowed, by 2 observers from the deck ( $3.5 \mathrm{~m}$ above sea level) and one on a raised platform (A-frame) near the stern (5.5 $\mathrm{m}$ above sea level). Surveys were carried out when the Beaufort sea state was 5 or less and visibility levels were good.

Vessel speed and heading, wind speed and direction, sea state, weather conditions and visibility were recorded using the software Logger 2010르. These data were updated every hour, or if the observer, sea state or visibility conditions changed. They were also recorded with every sighting.

When cetaceans were sighted, information on species identity, group size, bearing and distance from the ship were logged. When possible, photographs for species and individual identification (photo-ID) purposes were obtained for all baleen whales sighted (Payne et al. 1983, Kraus et al. 1986, Patenaude \& Baker 2001). Specific information on photographs for photo-ID and health assessment of SRWs is described below. Sightings for which species identification was not possible were classified to the lowest taxonomic level possible. Sighting data were plotted using ArcMap 10.4.1 (ESRI), with a high resolution $(100 \mathrm{~m})$ marine landscape map produced by Hogg et al. (2016) for background context (see Fig. 3).

Skin and blubber biopsy samples were collected during the survey using small, stainless steel biopsy darts deployed from a crossbow (Lambertsen 1987) or a Paxarm modified veterinary capture system (Krutzen et al. 2002). After a biopsy attempt, darts and/or samples were retrieved via tether system reel or a dip net. Skin biopsy samples were divided into subsamples for genetics, or stable isotope and hormone analysis, and stored in $95 \%$ ethanol or frozen at $-80^{\circ} \mathrm{C}$, respectively.

\subsection{Passive acoustic monitoring and tracking of SRWs}

Directional frequency analysis and recording (DIFAR) sonobuoys (HIDAR SSQ-955A, Ultra Electronics) were used to acoustically locate and track SRWs in real-time, and to record their vocalisations.

\footnotetext{
$\underline{2}$ The logger software at www.marineconservationresearch. co.uk was developed by the International Fund for Animal Welfare (IFAW) to promote benign and non-invasive research.
}

DIFAR sonobuoys contain an omnidirectional acoustic pressure sensor and 2 orthogonal acoustic vector sensors that are directional in the horizontal plane (Greene et al. 2004, McDonald 2004). Sonobuoy signals were received by VHF radio onboard the research vessel, digitised, recorded, processed using PAMGuard (Gillespie et al. 2009), and the DIFAR bearings to calls resolved as described by Miller et al. $(2015,2016)$. Continuous recordings were made at a sample rate of 48000 samples $\mathrm{s}^{-1}$, and data from all buoys were monitored and processed both visually and aurally by an on-duty acoustician and processed in real-time as they were received for the full duration of each buoy deployment.

VHF signals were received using a Procom CXL 2$3 \mathrm{LW} / \mathrm{s}$ omnidirectional antenna tuned to the 137$150 \mathrm{MHz}$ frequency band giving a gain of $3 \mathrm{dBd}$. The antenna was initially mounted at the top of the mast at a height of $33 \mathrm{~m}$, giving an effective reception range to the sonobuoys of around $20 \mathrm{~km}$. Problems with the mast head fitting meant that the antenna had to be moved to a fiberglass pole mounted on the A-frame with a height to the base of the antenna of $9.4 \mathrm{~m}$. This reduced the effective reception range to $12 \mathrm{~km}$. Sonobuoys were deployed in wind speeds of up to 35 knots because background noise levels were considered too high for effective monitoring at higher wind speeds. Sonobuoys were deployed to a depth of either $30 \mathrm{~m}$ (in waters shallower than $200 \mathrm{~m}$ ) or $140 \mathrm{~m}$ (in water deeper than $200 \mathrm{~m}$ ). After each buoy was deployed, it was subsequently monitored with the vessel within VHF range in order to detect calls and their associated bearings. Buoys were usually deployed overnight to allow the vessel to follow bearings to areas where SRWs had been detected before the commencement of visual observations in the morning. Further buoys were deployed and the vessel course altered in order to determine a more precise whale location and enable visual detections. In addition to deploying sonobuoys to search for whales, some buoys were deployed close to whale groups in order to match visual and acoustic observations. Because the vocalisations of SRWs on their feeding grounds are not well described, it was necessary to characterise their acoustic repertoire, and to attempt to differentiate them from humpback whales Megaptera novaeangliae, which are also present near South Georgia. This was achieved when acoustic bearings could be followed until the animals were located visually, or when the acoustic bearings to received calls could be aligned with known whale locations from a visual sighting. Analyses of these data are ongoing. 


\subsection{Photo-ID catalogue compilation and matching}

Individual adult SRWs can be identified by their unique patterns of head callosities and skin pigmentation (Payne et al. 1983, Kraus et al. 1986). All South Georgia SRW photographs obtained in this study were evaluated for image suitability and were assigned a quality rating from 0 (lowest quality) to 3 (highest quality), following the approach taken by Wade et al. (2011). The ratings were based on the following criteria (listed in order of importance): oblique angle, focus, amount of visible callosity pattern and exposure. Only images of quality 2 or 3 were used for individual identification purposes, yet all images were analysed and retained for health assessment and future photo-ID comparisons.

SRW photographs taken from vessels often only capture the callosity patterns on the left or right sides of the head. Every effort was made in the field and during subsequent image analysis to link these images to an individual animal. All photographed individuals were given an ID number, but only SRWs with high-quality left and right head callosity images are considered definitely unique. Definitely unique animals do not match any other whales identified during this survey, whereas whales with only a left or only a right head photograph may represent the same individual and may appear in the catalogue twice.

Photographs provided from the South Georgia Museum's archive and other platforms of opportunity were collated, and high-quality photo-ID images selected for further analysis. These photographs were compared to the BAS South Georgia photo-ID catalogue by an experienced matcher, and if the head callosity pattern did not match with any other photoidentified whale, this photograph was added to the catalogue as a unique individual. The photo-ID catalogue was also compared against the 12 whales photographed during the 1997 South Georgia expedition (Moore et al. 1999).

The 2018 South Georgia photo-ID catalogue was compared to wintering ground catalogues from (1) the Península Valdés (6887 images, 3255 individuals) using the software package BigFish (Skadia); (2) Brazil (921 unique individuals; Groch 2018); and (3) South Africa (2084 individuals; Best 1990), the latter 2 catalogues using the Hiby-Lovell software system to assist with matching. Cross-catalogue matching was complicated because photographs from wintering grounds were collected from aerial platforms and those from South Georgia were obtained from boats, with the BigFish and Hiby-Lovell systems requiring different amounts of photographic coverage of the head. Consequently, from the South Georgia photoID catalogue, 13 individuals could be compared with the Península Valdés catalogue, and 7 individuals compared with the Brazilian catalogue and with the South African catalogue.

\subsection{Visual health assessment}

South Georgia SRW side-on photographs were also analysed to quantify certain aspects of individual health. The complete set of images was scored by one researcher with substantial past experience analysing right whale photographs for photo-ID and body condition. Images were scored for the following 4 parameters: body fat condition, skin condition, rake marks near the blowhole and cyamids around the blowhole (Pettis et al. 2004; Table S1 in Supplement 2 at www.int-res.com/articles/suppl/n043p323_supp2. pdf). Standard health assessment analyses require the scoring of rake marks on both sides of the blowhole (Pettis et al. 2004), yet due to the paucity of images available for this study, we assumed the same score for both left and right sides in individuals for which photographs of only one side were available.

\subsection{Stable isotope analyses of SRWs and putative prey}

Putative prey species including Antarctic krill Euphausia superba and other zooplankton were collected from western South Georgia waters during December 2017 and January 2018 on the BAS Western Core Box cruise (cruise no. JR17002), for the purpose of identifying potential SRW prey species via stable isotope analysis of carbon and nitrogen. To establish the trophic position of SRWs in the South Georgia food web compared to other pelagic krill predators, some myctophid species were also collected for analysis. Myctophids in this region feed predominantly on copepod and euphausiid species so were anticipated to have similar isotopic signatures to the SRWs (Saunders et al. 2019). Samples were stored frozen at $-80^{\circ} \mathrm{C}$. Whale skin tissues were sampled approximately 1 mo after the zooplankton samples were taken. Samples were prepared for stable isotope analysis at the BAS and sent to the Scottish Universities Environmental Research Centre (SUERC) isotope facility (East Kilbride, UK) for analysis. All zooplankton and fish samples were lipid-extracted prior to carbon isotope analysis (following Reid et al. 2012). Whale skin samples were 
both lipid-extracted and gelatinised following the standard laboratory protocol of the Department of Archaeology, University of Cambridge (as detailed by O'Connell et al. 2001).

\subsection{Sightings from platforms of opportunity}

To both augment our data and place our SRW expedition work in the broader context of whale recovery at South Georgia, we undertook analyses of sightings from platforms of opportunity. Prior to and during the expedition, we promoted the collection of SRW photo-ID images within the International Association of Antarctic Tour Operators tourist and naturalist cruise-going community via informative lectures, circulation of leaflets and through social media outlets. As part of this campaign, we requested that visitors submit SRW photo-ID images to www.happywhale .com (hereafter referred to as Happywhale). Additional sighting data have been collated by the South Georgia Museum from other mariners (e.g. Richardson et al. 2012), and sightings recorded by GSGSSI Fisheries Protection vessels were provided directly to the authors (see Table S3).

South Georgia Museum sightings reports from 1992-2018 were examined and collated by year and species. These reports were mostly contributed by expedition ship naturalists and mariners and provided the location of each species sighted and an estimate of the numbers of animals seen during the sighting. Sighting reports were limited to the area $50^{\circ}-58^{\circ} \mathrm{S}$ and $33.5^{\circ}-43^{\circ} \mathrm{W}$, which includes Shag Rocks and the South Georgia region and continental shelf waters. Only baleen whale and sperm whale sightings were summarised, providing annual sightings rates for all large whales. Due to uncertainties as to whether English or American date notation were used in original reporting, sightings were binned by year rather than season. A number of caveats must be considered in relation to these data; sightings reported to the museum are opportunistic, are a small snapshot of the whales sighted locally, are biased towards coastal areas and the quality of reporting can vary considerably. Here, we focus on the sightings reported for humpback and SRWs, because these are both commonly reported and are particularly visually distinctive species relative to other rorqual whales sighted in the region.

The annual sightings for humpback and SRWs were collated, as well as total numbers of animals reported. The relative frequency of sightings of each species in relation to all whale species sighted was also calcu- lated, in order to provide a sightings measure that is independent of increasing visitor numbers through time. Sighting reports from GSGSSI fishery protection vessels the 'Dorada' (2003-2004) and the 'Pharos' (2016-2018) were summarised separately. Counts were sometimes reported to the museum as a range, or as a minimum number (i.e. $x+$ ). For ranges, the lower value was taken, and for minimum numbers only the minimum value was used, to provide conservative estimates from these opportunistic sightings.

\section{RESULTS}

\subsection{Survey effort and visual observations}

Weather and sea conditions were suitable for visual observations for $76 \mathrm{~h}$ (within $12 \mathrm{~d}$ out of $19 \mathrm{~d}$ spent in South Georgia waters) and spanned 327 nautical miles of survey. Cruise tracks during observation periods are illustrated in Fig. 3. A total of 36 cetacean sightings were recorded during the expedition (Table 2). Fifteen sightings of 31 SRWs were documented (Fig. 3); 11 of these encounters were of singletons or pairs, and the largest group sighted was estimated at 5 whales. No surface feeding behaviour by SRWs was observed during the expedition. The most notable behavior corresponded to long, repeated dives, estimated at $>9$ min in duration, performed by singletons (at least 6 different individuals). Biopsy sampling was attempted 7 times on 6 SRWs and 1 humpback whale. Four biopsy samples were collected (from 3 SRWs and 1 humpback whale). The SRWs were subsequently sexed by genetic analysis; 2 were females and 1 was male (details of genetic analyses are summarised in Carroll et al. 2020). Two of these samples ( 1 female, 1 male) provided sufficient tissue for stable isotope analysis.

\subsection{Passive acoustic monitoring}

A total of 27 sonobuoys were deployed between 25 January and 17 February. Six were deployed in the western approaches to South Georgia, and 21 were deployed in locations around the island's northern coastline and shelf. All of the 27 deployed sonobuoys functioned correctly. A total of $85.5 \mathrm{~h}$ of recordings were made, and around 3500 calls were detected and processed to calculate their bearings. SRWs were confidently detected on 13 buoys and detected with less certainty on a further 6, for a total of 19 buoys with detections (Fig. S1). The most commonly heard 
call types were upcalls $<200 \mathrm{~Hz}$; some gunshot calls were also detected. These 2 call types have previously been described for North Pacific and North Atlantic right whales on calving and feeding grounds and for SRWs on calving grounds; upcalls (but not gunshots) have also been described from SRWs on feeding grounds (Širović et al. 2006, 2015, Mellinger et al. 2007, Munger et al. 2008, Parks et al. 2011, Matthews et al. 2014, Soldevilla et al. 2014, Webster et al. 2016, Crance et al. 2017, Dombroski et al. 2017). Call rates were generally low, with periods of silence of several hours, making triangulation using multiple buoys challenging. Acoustic detections of Antarctic blue whales Balaenoptera musculus intermedia, fin whales Balaenoptera physalus, humpback whales, sperm whales Physeter microcephalus and killer whales Orcinus orca were also documented on the sonobuoys (see Table S2).

\subsection{Photo-ID catalogue compilation and matching}

Of the approximately 1880 images collected during SRW encounters, 1032 images were of sufficient quality and angle to be retained for photo-ID and health assessment analysis. An additional 64 oppor-

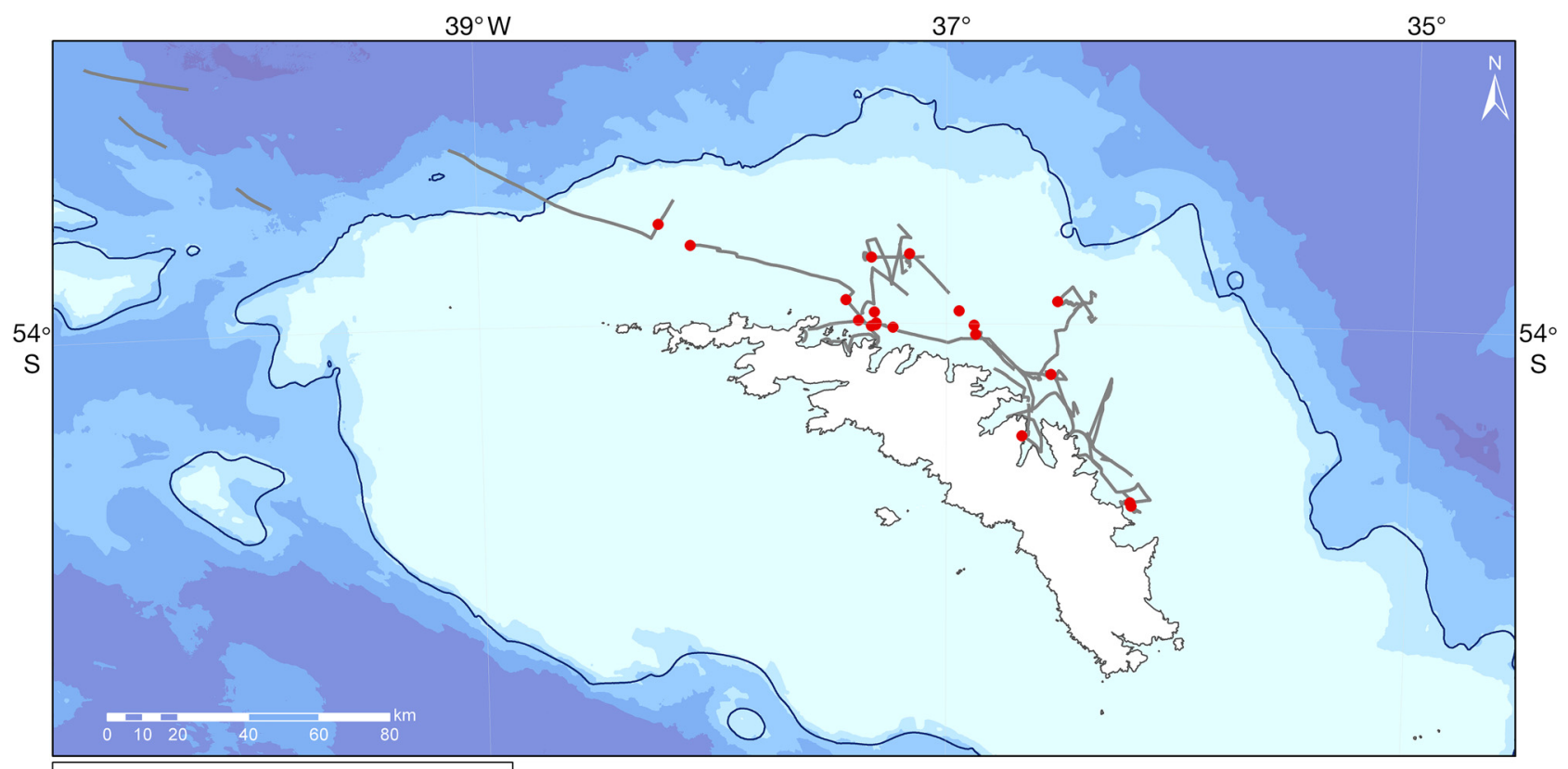

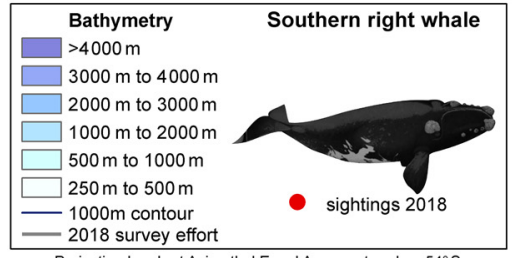

Projection Lambert Azimuthal Equal Area centered on $54^{\circ} \mathrm{S}$
Fig. 3. South Georgia, showing vessel tracks and southern right whale visual sightings from the 2018 cruise

Table 2. Total individuals, group sizes (shows minimum and maximum estimated group size) and sightings for each species encountered in South Georgia waters

\begin{tabular}{|c|c|c|c|c|c|c|}
\hline Scientific name & Common name & $\begin{array}{c}\text { Total } \\
\text { individuals }\end{array}$ & $\begin{array}{c}\text { Total } \\
\text { sightings }\end{array}$ & $\begin{array}{l}\text { Median } \\
\text { group size }\end{array}$ & $\begin{array}{l}\text { Group } \\
\text { size }\end{array}$ & $\begin{array}{l}\text { Photo-ID } \\
\text { collected? }\end{array}$ \\
\hline \multicolumn{7}{|l|}{ Mysticetes } \\
\hline Eubalaena australis & Southern right whale & 31 & 15 & 2 & $1-7$ & $\mathrm{Y}$ \\
\hline Megaptera novaeangliae & Humpback whale & 6 & 2 & 3 & $2-4$ & Dorsal only \\
\hline Balaenoptera physalus & Fin whale & 7 & 1 & 7 & $5-9$ & $\mathrm{Y}^{1}$ \\
\hline Balaenoptera musculus intermedia & Antarctic blue whale & 3 & 1 & 3 & 3 & $\mathrm{Y}$ \\
\hline Balaenoptera bonaerensis & Probable Antarctic minke whale & 1 & 1 & 1 & 1 & $\mathrm{~N}$ \\
\hline Unidentified mysticete & & 5 & 4 & 1 & $1-2$ & $\mathrm{~N}$ \\
\hline
\end{tabular}


tunistic photographs taken during commercial cruises to the region were submitted to Happywhale and have been added to the photo-ID catalogue. Analysis of these images resulted in 35 assigned ID numbers (photo-IDs of medium or high quality). There were 11 individuals with high-quality left photos, 15 with high-quality right photos and 6 definitely unique individuals with high-quality left and right photos).

No matches were found in a comparison of images from the 2018 South Georgia expedition and the wintering ground catalogues from South Africa, Brazil and Península Valdes or between the 2018 South Georgia expedition and the 12 images collected during the 1997 South Georgia expedition (Moore et al. 1999).

\subsection{Health assessment}

A total of 26 of the 35 photo-identified whales had adequate photographic coverage to support a complete health assessment (Table 3). Four of the 35 whales identified in this study could not be assessed for any of the 4 health parameters due to a lack of adequate imagery of the associated body region. An additional 5 whales could only be partially scored. The assessment included animals with photos of only one side of the head, as rake mark scores were assumed to be the same for both sides in this study.

The cumulative scaled health score for individual animals ranged from 12 (the lowest, or 'healthiest' animal) to 21 with an overall mean $( \pm \mathrm{SD})$ of $15.4 \pm 2.9$. The maximum possible score (i.e. the poorest possible health assessment) was 30. More than half of the SRWs analysed here received a 'Good' rating for each of the 4 parameters overall (Table 3 ), and no SRW received a 'Poor' body condition or rake marks rating. However, $41.9 \%$ of animals analysed for body condition were characterized as 'Medium', indicating some level of body fat loss in the cervical region immediately caudal to the blowholes, and $35.7 \%$ were given a 'Poor' skin condition rating due to patches of sloughed skin, cyamids or lesions on the body. Rake marks were somewhat prevalent $(40 \%$ left side and $35.3 \%$ right side) near the blowholes as well. No whales with appropriate imagery displayed any significant cyamid coverage around the blowholes. There were no obvious signs of current or previous entanglement observed. Examples of the image assessment are shown in Fig. S2A-F.

Inspection of the South Georgia catalogue also revealed the presence of kelp gull lesions on some animals (e.g. Fig. S2G). Lesions were positively identified on 4 whales and were possibly identified on another 3 animals.

\subsection{Stable isotope analysis}

Samples of 10 zooplankton species and 4 midwater fish species were collected during the Western Core Box cruise (JR17002). Stable isotope data were also obtained from 2 South Georgia SRWs for comparison. Zooplankton and fish species showed a wide variety of both $\delta^{13} \mathrm{C}$ and $\delta^{15} \mathrm{~N}$ values within and between species (Fig. 4). Stable isotope $\delta^{13} \mathrm{C}$ values ranged from $-26.5 \%$ in particulate organic matter to $-16.4 \%$ in the copepod Calanoides acutus. A general enrichment was found from primary (e.g. Salpa spp.,) to secondary consumers (e.g. Themisto gaudichaudii, Paraeuchaeta spp.) with considerable overlap in values among taxa (Table S3). Values of $\delta^{15} \mathrm{~N}$ ranged from $1.9 \%$ in filter feeding salps to $9.9 \%$ in the predatory myctophid fish Gymnoscopelus piabilis. As for carbon isotope ratios, nitrogen values showed a continuous rather than stepwise increase from filter and suspension feeders to secondary consumers.

SRWs were enriched by $2.3-4.0 \%$ in $\delta^{15} \mathrm{~N}$ relative to euphausiid species and by $1.5-2.7 \%$ relative to various copepod species. Both whale specimens showed similar $\delta^{5} \mathrm{~N}$ and $\delta^{13} \mathrm{C}$ values to the majority of myctophid fish species analysed, and Krefftichthys anderssoni and Gymnoscopelus fraseri in particular (Fig. 4). Of the 2 specimens analysed, the tissue of the male specimen (EAU-SG01) was slightly enriched in $\delta^{15} \mathrm{~N}(8.7 \%)$ and depleted in $\delta^{13} \mathrm{C}(-21.2 \%)$ compared to the female (EAU-SG02, 7.6 and $-20.7 \%$ ).

Table 3. South Georgia right whale health condition assessed using the visual assessment approach of Pettis et al. (2004). Percentage of animals with each assessment shown in parentheses. L and R: left and right side of the whale; n/a: not applicable

\begin{tabular}{|lccccc|}
\hline & Body condition & Skin condition & Rake marks L & Rake marks R & Cyamids \\
\hline No. assessable & 31 & 28 & 20 & 17 & 28 \\
Good (\%) & $18(58.1)$ & $18(64.3)$ & $12(60)$ & $11(64.7)$ & $28(100)$ \\
Medium (\%) & $13(41.9)$ & n/a & $8(40)$ & $6(35.3)$ & 0 \\
Poor (\%) & 0 & $10(35.7)$ & 0 & 0 \\
\hline
\end{tabular}




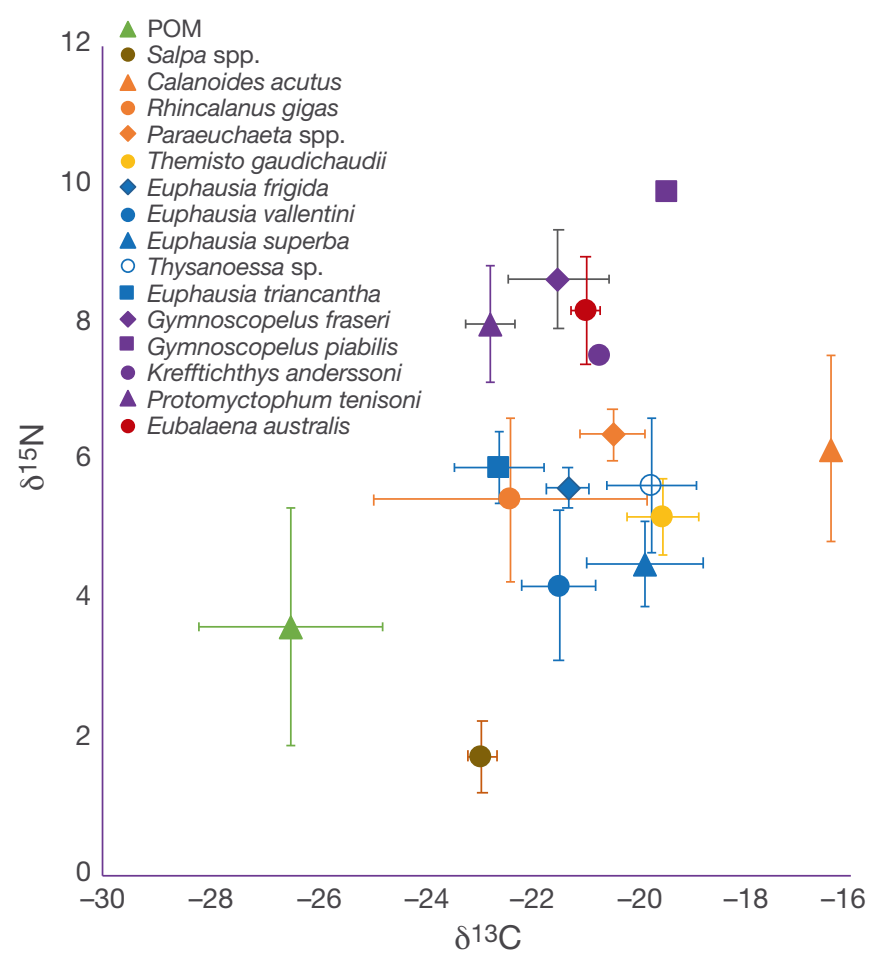

Fig. 4. Carbon $\left(\delta^{13} \mathrm{C}\right)$ and nitrogen $\left(\delta^{15} \mathrm{~N}\right)$ stable isotope values for southern right whales, putative food sources (copepods and euphausiid krill) and a selection of other mesopelagic groups from the South Georgia food web. Red: southern right whales; green: particulate organic matter; brown: tunicates; orange: copepods; yellow: amphipods; blue: euphausiid species; purple: myctophid fishes

\subsection{Opportunistic whale sightings}

The distribution of opportunistic SRW and humpback whale sightings reported to the South Georgia Museum since 1992 is shown in Fig. 5A,B. The distribution of opportunistic sightings reported by fishery protection vessels during 2003-2004 and 2016-2018 is shown in Fig. 5C,D. Museum reports suggest the 2 species have similar sighting patterns in the areas that vessels usually transit (passing Shag Rocks and close to the north coast). However, because fishery protection vessels transit through areas less commonly visited by tourist vessels (e.g. the South Georgia shelf break at the 1000 m contour), sightings from these vessels show some contrast in the distribution
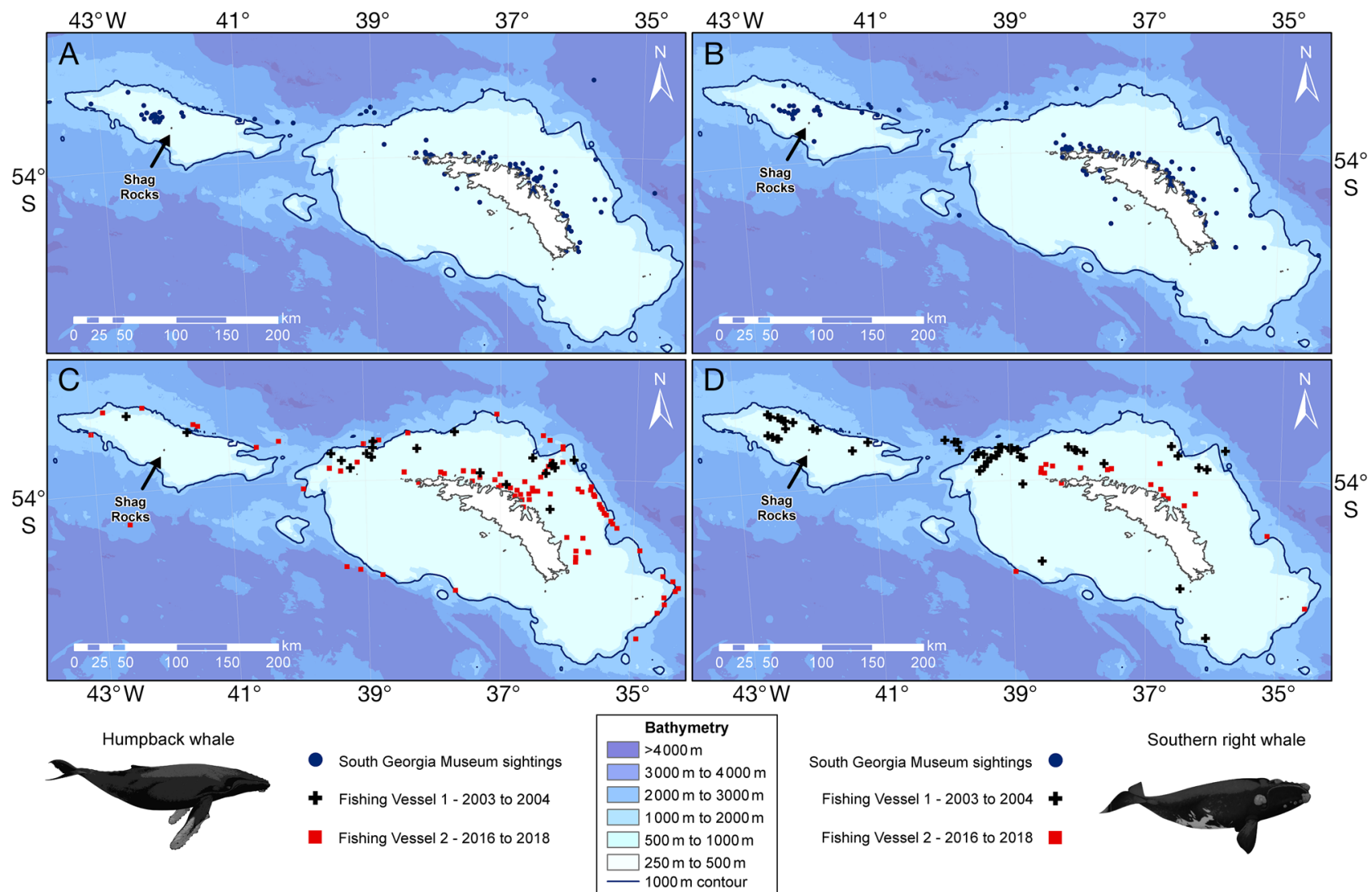

Southern right whale

Fishing Vessel 2 - 2016 to 2018

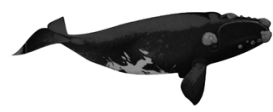

Fig. 5. Distribution of $(A, C)$ humpback and $(B, D)$ southern right whale sightings in South Georgia waters; $(A)$ and $(B)$ show sightings reported to South Georgia Museum from 1992-2018; (C) and (D) show sightings recorded by fishery observer vessels during 2003-2004 and 2016-2018 
of the 2 species. For example, SRWs are not seen as commonly as humpback whales at the South Georgia shelf break. The distribution of humpback whale sightings by the fishery protection vessels was similar in 2003-2004 and 2016-2018. In contrast, more SRW sightings were documented in 2003-2004 than in 2016-2018, with clusters of sightings recorded at the shelf break west-north-west of South Georgia, and in the vicinity of Shag Rocks.

Relative sighting frequencies indicate that the SRW was the most commonly seen species in South Georgia waters between 1999 and 2010 (Fig. 6, Table S4). Since 2010 the pattern is more variable, with humpback whales being more regularly sighted from 2013-2018, with the exception of 2015 (Fig. 6A,B). The fishery protection vessel data shows a similar
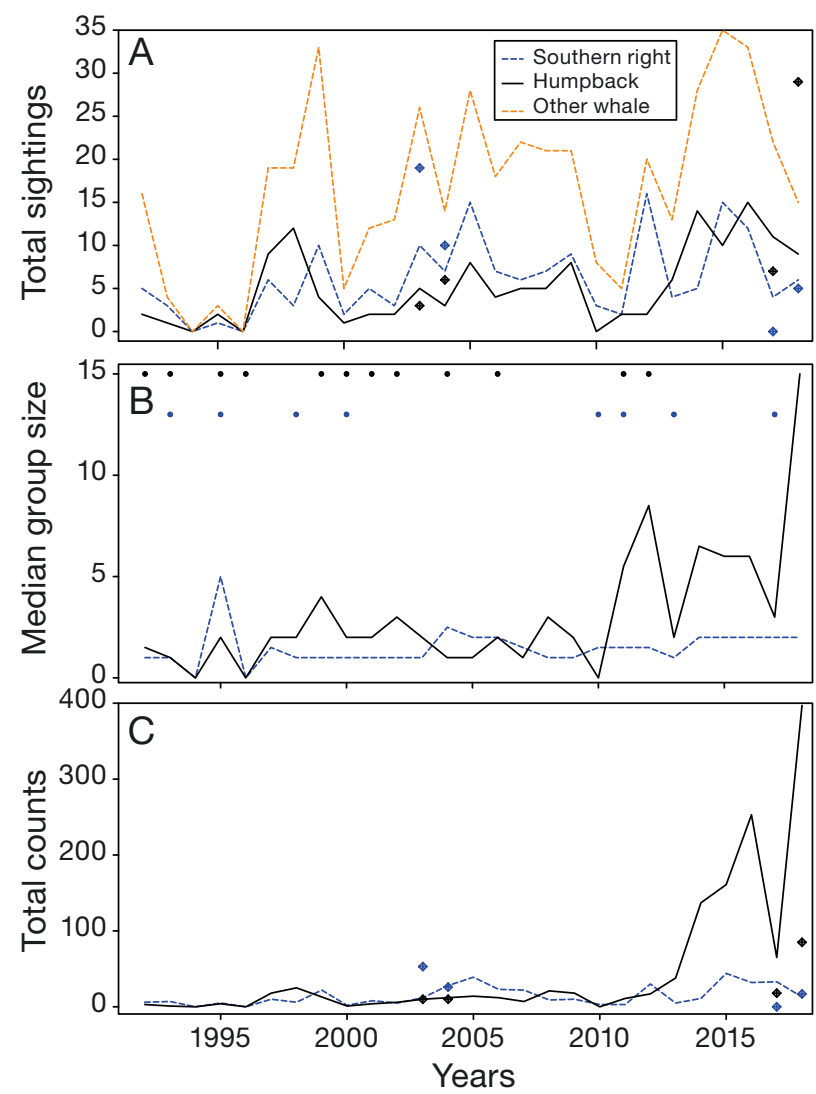

Fig. 6. Whale sightings reported to South Georgia Museum from 1992-2018 from within the South Georgia area (33.5$43^{\circ} \mathrm{W}$ ). Plotted lines: non-fishery vessel sightings; points: sightings reported by fisheries protection vessels. (A) Total numbers of sightings reported, (B) median group sizes reported (dots at the top of the plot show years where less than 5 observations were available, coloured by each respective species) and (C) total counts of whales reported. In each case, blue dotted line: southern right whale sightings; black solid line: humpback whale sightings; orange dotted line: other whale species (baleen and sperm whales) sighted in South Georgia waters pattern, with more SRW sightings during January 2003 and 2004 and more humpback whale records in January 2017 and 2018. Species counts show fairly stable numbers of both species reported over time until 2013. After this year, total counts of humpback whales have increased by $3-10 \times$ (from $<40 \mathrm{yr}^{-1}$ to $>250$; Fig. 6 C). This reflects an increase in the group sizes reported rather than the total numbers of sightings (Fig. 6B). In contrast, higher counts of SRWs between 2004 and 2007 reflected an increase in total sightings at that time, with no change in the group sizes reported.

\section{DISCUSSION}

\subsection{SRW habitat use}

SRWs were frequently encountered in South Georgia during the 2018 survey, supporting previous conclusions by Moore et al. (1999) and Richardson et al. (2012) that they occur regularly off the north coast in summer. SRWs were also regularly detected acoustically, as they were heard on at least 13 of the 21 sonobuoys deployed in South Georgia waters. However, the small estimated SRW group sizes observed during this survey (median group size $=2, \mathrm{SD}=1.2$ ) and in past reports to the South Georgia Museum (from 2014-2019, median group size $=2, \mathrm{SD}=2.1$ ) indicate perhaps small group foraging activity or travelling. During the survey, some whales were observed making repeated dives of $>9$ min duration. Their target prey were most likely to be krill or copepods, based on previous studies (Matthews 1938, Valenzuela et al. 2009, 2018) and the current isotope data. Similarly long dive profiles of $\sim 10$ min duration and $\sim 50 \mathrm{~m}$ depth have also been recorded in Argentine Patagonia (Argüelles et al. 2016); in that case it was suggested that those whales were feeding on lobster krill (the Grimothea post-larvae of Munida gregaria), consistent with previous observations by Matthews (1932). Historical stomach contents data suggests whales at South Georgia fed on krill rather than copepods (Matthews 1938, Tormosov et al. 1998), but sample sizes were very small as very few SRW diets were analysed. Active acoustic analysis of the prey field in the vicinity of SRWs exhibiting this diving behaviour could provide more insights into the target prey.

Stable isotope analyses of whale feeding patterns at Península Valdés provide a general indication of whether SRWs are feeding at high or low latitudes (Rowntree et al. 2008, Valenzuela et al. 2009, 2018). Stable isotope signatures were available from just 2 
SRWs at South Georgia, so we can only make limited interpretation from these data. These 2 SRWs had carbon and nitrogen isotopic values within the same range as the 'high latitude' SRW feeding group previously identified by Valenzuela et al. (2018). Since the isotope signature of food is thought to take 1-3 mo to be incorporated into whale skin tissue (Borrell et al. 2012) and the South Georgia samples were collected in January, the pattern suggests that these whales were likely feeding at high latitudes during late spring, and so may have been present in the vicinity of South Georgia for 2 mo or more. If we assume a tissue discrimination factor in nitrogen of $2.8 \%$ between whale skin and their candidate zooplankton prey (Borrell et al. 2012), these data suggest that these SRWs were likely to be feeding on local copepods and/or euphausiids, but these prey sources could not be distinguished as they have overlapping stable isotope signatures (Fig. 4). The 2 myctophid fish species closest in isotopic values to the SRW (Krefftichthys anderssoni and Gymnoscopelus fraseri) feed on a mixture of Thysanoessa krill and copepod species (Metridia spp. and Rhincalanus gigas, respectively) (Saunders et al. 2019). Myctophid and SRW isotopic signatures suggest both predators feed at a similar trophic level and potentially have similar prey niches in South Georgia waters. Further analyses of fatty acids and compound-specific isotopes of whales and their candidate zooplankton prey could help to better distinguish the species of prey being consumed at South Georgia.

Habitat modelling of SRW feeding patterns using $19^{\text {th }}$ and $20^{\text {th }}$ century offshore whaling data suggests that SRWs forage in proximity to oceanographic features that act to aggregate prey patches, such as thermoclines and currents (Torres et al. 2013, González Carman et al. 2019). In the southwest Atlantic, SRWs have a broad summer feeding range, which includes the Patagonian Shelf (Rowntree et al. 2001), Scotia Sea (Moore et al. 1999, Reilly et al. 2004) and historically also offshore waters $30^{\circ}-45^{\circ} \mathrm{S}$ (Smith et al. 2012). Stable isotope studies conducted on their main calving ground at Península Valdés suggest that the majority of whales feed south of the Polar Front before returning to the calving grounds (Valenzuela et al. 2009, 2018), but recent satellite tracking studies indicate that this area spans much of the Scotia Arc (Zerbini et al. 2016, 2018). South Georgia is therefore one of a number of sites where SRWs feed during the summer. Patterns of SRW sightings by visitors to South Georgia are very coastal, reflecting the areas where the vessels are most concentrated and spend most time. However, fisheries pro- tection vessels travel further offshore and routinely survey out to the shelf break. Sightings reports from these vessels show a number of reports due westnorthwest of the island within shelf waters, and further west offshore at Shag Rocks (Fig. 4D). Shelf waters west of the island also appear important to SRWs satellite tracked from their Argentine calving areas. For example, 'area restricted searching' (ARS) behaviours (locations where whales stop migrating and remain for extended periods) have been seen in South Georgia shelf waters just off the western edge of the island (Zerbini et al. 2018), and to the east of South Georgia, further offshore (beyond the $1000 \mathrm{~m}$ contour). Tracking of krill-feeding Antarctic fur seals in 2005-2006 also showed seals concentrating their feeding dives in the same 2 locations (Staniland et al. 2011), suggesting that these areas may be a predictable, or important, source of krill for both species. This westerly area may have also been a historically important site for SRWs; Matthews (1938) quotes Hinton (1925, p. 155) as saying 'In 1914 Barrett Hamilton was told that SRW were taken when found with other species, but that they usually kept themselves to the north-west of South Georgia and were not worth hunting, especially there'. Higher levels of chlorophyll a productivity and iron are found at the northwest end of the island compared to the northeast, supporting a higher biomass of krill — and, as a corollary, krill predators - in the western part of South Georgia, possibly also enhanced by nitrogen feedbacks from the krill predators (Whitehouse et al. 1999, Korb \& Whitehouse 2004). Further studies to track SRWs in this region and analyse habitat use patterns will help to better establish the significance of these locations, and of the different prey sources that SRWs could be targeting.

\subsection{Origin and body condition of South Georgia SRWs}

At least 3 individuals photo-identified at South Georgia had wounds consistent with gull lesions, which link them directly to Península Valdés in Argentina because it is the only calving area where gulls currently harass whales (IWC 2011, 2016). This is consistent with linkages directly identified by past photo-ID matching (Rowntree et al. 2001) and recent satellite tracking of whales directly between these locations (Zerbini et al. 2018). However, no individually identified whales from the South Georgia catalogue were directly connected with any lower latitude calving grounds in this study, despite com- 
parison with the sizeable photo-ID catalogues held in Argentina, Brazil and South Africa. This is likely because in South Georgia, photo-ID images were taken from the side, and could not easily be compared with the calving grounds because the calving ground photo-IDs are taken overhead. The Península Valdés catalogue represents a large proportion of all whales using Argentine waters, with 3034 individuals present in the catalogue in 2015 compared to a population abundance estimated at 4245 in 2010 (IWC 2013). Thus, if South Georgia whales all visit this region, the chance of a match should be high. However, the likelihood of matching is reduced if the whales sighted at South Georgia were young, as this cohort is the least well represented in the calving ground catalogue (the average age for first reproduction in SRWs is 8 yr old; Best et al. 2001). Some of the whales on the South Georgia survey were recorded as being small in size, and therefore may have been juveniles (they were not small enough to be definitely categorised as calves); therefore, they may have been less likely to be present in the Península Valdés catalogue. Collection of overhead images from South Georgia is challenging due to the remoteness of the region (which prohibits aerial surveys) and local weather conditions which limit data collection via unmanned aerial vehicle (UAV). Only South Georgia images which show both sides of the head could be used in comparisons with the calving grounds. More collection of side-on images from the calving grounds could improve the likelihood of photo-ID matching with South Georgia in the future.

Kelp gull wounds seen on 3 whales confirm the connection with Argentina, since this gull behaviour is widespread on the Península Valdés calving area and is also unique to the region (Marón et al. 2015). This connection is corroborated by regional genetic patterns. Genetic data collected from the expedition was assembled along with earlier genetic data collected by Moore et al. (1999) to assess the population origins of the South Georgia whales. Mitochondrial DNA and nuclear microsatellites supported a putative link with the southwest Atlantic, showing that SRWs from South Georgia are genetically more closely linked to the southwest Atlantic calving grounds (Brazil and Argentina) than to the southeast (South Africa) (Carroll et al. 2020), consistent with the migratory movements suggested by satellite tracking studies (Mate et al. 2011, Zerbini et al. 2018).

Our body condition analyses provide a baseline data set for assessing the seasonal health condition of SRWs in South Georgia waters, for comparison with other regions, including their associated calving grounds, and for measuring local changes in body condition over time. None of the South Georgia SRWs analysed received a 'Poor' score for all 4 health parameters, but $\sim 36 \%$ of whales were assessed as having 'Poor' skin condition and $\sim 42 \%$ as 'Medium' body condition due to a lack of fat in the cervical region caudal to the blowhole (i.e. they are thin). In the North Atlantic, Pettis et al. (2004) reported a mean body condition score for known cows without a calf of 1.08 and cows with a calf of 1.67. These values are similar to our mean body condition results $(1.15 \pm$ 1.49) Overall, North Atlantic right whale health parameter scores were higher (reflecting poorer condition) during calving years and for presumed dead whales (Pettis et al. 2004), underscoring the fact that visual health assessment methods are useful for measuring individual fitness when individuals are assessed over multiple seasons. A similar pattern has been seen using overhead images (Christiansen et al. 2020), with juvenile, adult and lactating female SRWs across 3 calving grounds found to be in better body condition than North Atlantic right whales at equivalent stages.

The overall health of the surveyed animals (assessed using the scoring system of Rolland et al. 2016) was good, with average values of 0.81 ( $\mathrm{SD}=0.09$ ); higher than those of all the demographic cohorts of North Atlantic right whales assessed by Rolland et al. (2016). At present, these results cannot be compared with other SRW populations, as body condition assessment using side-on images has not been published for any other SRW populations. This is because calving ground studies routinely use overhead, rather than side-on, images. For example, body condition analyses carried out by Argentina and South Africa both use size-calibrated overhead images of whales (photogrammetry) which can provide detailed information on whale growth rates and body fat variation during the calving period (e.g. Miller et al. 2012, Christiansen et al. 2018, 2020). Whales on their feeding grounds would be expected to gain in mass over the season (for an example with gray whales, see Bradford et al. 2012), but no photogrammetry work has been conducted on right whale feeding grounds to date to assess this in detail. Photogrammetry data collected from the feeding ground could provide quantitative information on SRW health which can be directly compared with the associated calving ground. There are difficulties in conducting this kind of research at South Georgia given the weather conditions, but as UAVs improve in terms of their stability and battery life, such data collection may prove more possible in the coming years. 


\subsection{Changing patterns of SRW and humpback whale occurrence}

Humpback whales were regularly detected by sonobuoys in South Georgia waters, although they were only sighted twice during the survey. Interestingly, sightings data from the South Georgia Museum suggest an increase in sighting rates of humpbacks relative to SRWs in recent years, with 5 out of the last 6 years reporting more humpback sightings than SRWs. This is in contrast to 2000-2010, when SRWs were the most commonly encountered species. The temporal pattern may be a consequence of the relative abundance of the 2 species as they recover in the southwest Atlantic; recent trends in abundance of the 2 species have been similar at $6.5 \pm 0.2 \% \mathrm{yr}^{-1}$ for SRWs between 2000 and 2010 (Cooke et al. 2015) and 6.1\% yr ${ }^{-1}$ between 2008 and 2012 for humpback whales (Bortolotto et al. 2017). However, while SRW abundance in Península Valdés was estimated at 4245 whales in 2010 and abundance off Brazil was likely less than 1000 animals in that year (197 mature females counted; IWC 2013), humpback whale abundance on their Brazilian wintering ground was estimated at 20389 whales (CV = 0.07) in 2012 (Bortolotto et al. 2017). In 2019, this population was predicted to be approaching 25000 (95\% probability interval $=22300-27000$ ) and to be very close to full recovery from exploitation (Zerbini et al. 2019). Southwest Atlantic humpbacks feed throughout the Scotia Arc in summer, across a broad feeding area that includes the South Sandwich Islands and areas to the east of that region (Zerbini et al. 2006, 2011, Horton et al. 2020). In South Georgia, museum sightings reports suggest humpback whale sightings were much less frequently reported prior to 2012. Their occurrence in South Georgia waters only recently suggests that as the population has increased, it has expanded from other areas of the Scotia Arc into South Georgia waters. The recent 'jump' in sightings may also support the hypothesis advanced by Clapham et al. (2008) that the southwest Atlantic humpback population lost the 'cultural memory' of South Georgia as an important feeding destination following prolonged hunting at South Georgia, wiping out the animals which had long-term fidelity to this region and therefore slowing the species' return.

The temporal pattern of SRW sightings does not suggest that SRW numbers are increasing on their South Georgia feeding ground (Fig. 5), despite a significant increase in cruise ships and associated opportunistic sighting effort since 1995 (IAATO 2020). This is in contrast to the steady SRW increases reported on their associated calving grounds (Groch et al. 2005, Cooke et al. 2015). Since SRWs use multiple feeding areas in the southwest Atlantic (Valenzuela et al. 2009, 2018, Zerbini et al. 2018), prey availability may limit the number of SRWs that feed in each location each year. However, while the relative sightings rates point towards a shift in the frequency of occurrence of SRWs and humpback whales over time, it must be cautioned that most of the sightings reports to the museum are from a narrow spatial area within South Georgia (the coastal waters and western approach to the island) and are not related to sighting effort, so caution must be applied when drawing biological interpretations from the relative sightings rates. South Georgia also has notoriously rough seas, particularly in deep water. SRWs display less of their back at the surface than humpback whales and have no dorsal fin, so may be less visible in rough conditions, particularly to vessels that do not have dedicated or experienced whale observers. SRW group sizes are also smaller than those of humpbacks, making them harder to detect. Line transect sightings surveys by experienced observers, spanning shelf and coastal waters, are required to quantitatively evaluate the relative densities of the 2 species.

\section{CONCLUSIONS}

The local ecosystem and climate into which baleen whales are recovering is very different from that of a century ago, when krill-feeding fur seals were absent and krill densities may have been much higher. Temporal trends in whale abundance over the last 20 yr cannot be strongly interpreted from opportunistic sightings data, since this depends on annually variable effort from visitors who follow similar coastal transit routes in South Georgia waters and who are not experts at cetacean identification. However, using these data to compare the fortunes of 2 easy-to-recognise species, and building on the literature reviewed in this study, we can develop some hypotheses for further investigation. For example, fisheries protection vessel data show a concentration of sightings of both species at the western shelf break between South Georgia and Shag Rocks (Fig. 4C,D), coincidentally also an area where satellite tracked SRWs have conducted ARS (e.g. foraging activities; Zerbini et al. 2018), suggesting that this area is important for whales. We have also seen large increases in humpback whale counts and group sizes since 2011 (Fig. 5). We expect that opportunistic whale sightings will continue to increase in the coming years and hypothesise that the western shelf break region is likely to be a hotspot for such sightings. 
Acknowledgements. This work was supported by funding from an EU BEST 2.0 Medium Grant 1594, with additional support provided by a DARWIN PLUS award DPLUS057 and additional funding from the World Wildlife Fund. This study forms part of the Ecosystems component of the British Antarctic Survey Polar Science for Planet Earth Programme, funded by The Natural Environment Research Council. We thank the Government of South Georgia and the South Sandwich Islands for providing support for this expedition, the photo-ID contributors to Happywhale, the volunteers at South Georgia Museum for compiling sightings data, Marie Shafi of South Georgia Heritage Trust, Flor Vilches for conducting photo-ID matching, Marine Conservation Research International for vessel charter support, Jonathan and Thom Gordon at Vanishing Point Marine, Jason Newton and Rona A. R. McGill at SUERC in East Kilbride, Paula Olson, Luciano Valenzuela, Norman Ratcliffe, Laura Gerrish, Steve Dent and the Veterinary Department in Stanley, and Heather Pettis for advice on right whale health analysis. E.L.C. was partially supported by a Rutherford Discovery Fellowship from the Royal Society of New Zealand.

\section{LITERATURE CITED}

Allison C (2013) IWC individual and summary catch databases version 5.5 (12 February 2013). International Whaling Commission, Cambridge

Argüelles MB, Fazio A, Fiorito C, Pérez-Martínez D, Coscarella M, Bertellotti M (2016) Diving behaviour of southern right whales (Eubalaena australis) in a maritime traffic area in Patagonia, Argentina. Aquat Mamm 42:104-108

Atkinson A, Whitehouse MJ, Priddle J, Cripps GC, Ward P, Brandon MA (2001) South Georgia, Antarctica: a productive, cold water, pelagic ecosystem. Mar Ecol Prog Ser 216:279-308

Best PB (1990) Trends in the inshore right whale population off South Africa, 1969-1987. Mar Mamm Sci 6:93-108

Best PB, Payne R, Rowntree VJ, Palazzo JT, Both MD (1993) Long-range movements of South Atlantic right whales (Eubalaena australis). Mar Mamm Sci 9:227-234

Best P, Brandao A, Butterworth D (2001) Demographic parameters of southern right whales off South Africa. J Cetacean Res Manag 2:161-169

* Borrell A, Abad-Oliva N, Gómez-Campos E, Giménez J, Aguilar A (2012) Discrimination of stable isotopes in fin whale tissues and application to diet assessment in cetaceans. Rapid Commun Mass Spectrom 26:1596-1602

Bortolotto GA, Danilewicz D, Hammond PS, Thomas L, Zerbini AN (2017) Whale distribution in a breeding area: spatial models of habitat use and abundance of western South Atlantic humpback whales. Mar Ecol Prog Ser 585: 213-227

Bradford AL, Weller DW, Punt AE, Ivashchenko YV, Burdin AM, VanBlaricom GR, Brownell RL (2012) Leaner leviathans: body condition variation in a critically endangered whale population. J Mammal 93:251-266

Carroll EL, Ott PH, McMillan LF, Galletti Vernazzani B and others (2020) Genetic diversity and connectivity of southern right whales (Eubalaena australis) found in the Chile-Peru wintering grounds and South Georgia (Islas Georgias del Sur) feeding grounds. J Hered 111:263-276

Christiansen F, Vivier F, Charlton C, Ward R, Amerson A, Burnell S, Bejder L (2018) Maternal body size and condition determine calf growth rates in southern right whales. Mar Ecol Prog Ser 592:267-281

* Christiansen F, Dawson SM, Durban JW, Fearnbach H and others (2020) Population comparison of right whale body condition reveals poor state of the North Atlantic right whale. Mar Ecol Prog Ser 640:1-16

Clapham PJ, Aguilar A, Hatch LT (2008) Determining spatial and temporal scales for the management of cetaceans: lessons from whaling. Mar Mamm Sci 24:183-201

Cooke J, Rowntree V, Sironi M (2015) Southwest Atlantic right whales: interim updated population assessment from photo-ID collected at Península Valdéz, Argentina. Paper SC/66a/BRG23 presented to the IWC Scientific Committee, May 2015

Crance JL, Berchok CL, Keating JL (2017) Gunshot call production by the North Pacific right whale Eubalaena japonica in the southeastern Bering Sea. Endang Species Res 34:251-267

de Morais IOB, Danilewicz D, Zerbini AN, Edmundson W, Hart IB, Bortolotto GA (2017) From the southern right whale hunting decline to the humpback whaling expansion: a review of whale catch records in the tropical western South Atlantic Ocean. Mammal Rev 47:11-23

*Dombroski JRG, Parks SE, Groch KR, Flores PAC, SousaLima RS (2017) Upcall production by southern right whale (Eubalaena australis) mother-calf pairs may be independent of diel period in a nursery area. Mar Mamm Sci 33:669-677

*Gillespie D, Mellinger DK, Gordon J, McLaren D, Thode A (2009) PAMGUARD: semiautomated, open source software for real-time acoustic detection and localization of cetaceans. J Acoust Soc Am 125:2547

* González Carman V, Piola A, O'Brien TD, Tormosov DD, Acha EM (2019) Circumpolar frontal systems as potential feeding grounds of southern right whales. Prog Oceanogr 176:102123

*Greene CR Jr, McLennan MW, Norman RG, McDonald TL, Jakubczak RS, Richardson WJ (2004) Directional frequency and recording (DIFAR) sensors in seafloor recorders to locate calling bowhead whales during their fall migration. J Acoust Soc Am 116:799-813

Groch KR (2018) Conservation advances for the southern right whales in Brazil. In: Rossi-Santos MR, Finkl CW (eds) Advances in marine vertebrate research in Latin America. Springer International Publishing, Berlin, p 441-475

*Goch KR, Palazzo JT Jr, Flores PAC, Adler FR, Fabian ME (2005) Recent rapid increases in the right whale (Eubalaena australis) population off southern Brazil. Lat Am J Aquat Mamm 4:41-47

Harcourt R, van der Hoop J, Kraus S, Carroll E L (2019) Future directions in Eubalaena spp.: comparative research to inform conservation. Front Mar Sci 5:530

Hart I, Edmundson W (2017) A history of whaling in Brazil: from royal fish to Japanese delicacy. Pequena, Newton St Margarets

Headland RK (1989) Chronology of Antarctic expeditions and related historical events. Cambridge University Press, Cambridge

Hedley S, Reilly S, Borberg J, Holland R and others (2001) Modelling whale distribution: a preliminary analysis of data collected on the CCAMLR-IWC krill synoptic survey, 2000. Paper SC/53/E9 presented to the IWC Scientific Committee, May 2001

Hinton MAC (1925) Report on the papers left by the late Major Barrett-Hamilton, relating to the whales of South Georgia. The Crown Agents for the Colonies, London 
Hoffman JI, Grant SM, Forcada J, Phillips CD (2011) Bayesian inference of a historical bottleneck in a heavily exploited marine mammal. Mol Ecol 20:3989-4008

*Hogg OT, Barnes DK, Griffiths HJ (2011) Highly diverse, poorly studied and uniquely threatened by climate change: an assessment of marine biodiversity on South Georgia's continental shelf. PLOS ONE 6:e19795

Hogg OT, Huvenne VAI, Griffiths HJ, Dorschel B, Linse K (2016) Landscape mapping at sub-Antarctic South Georgia provides a protocol for underpinning large-scale marine protected areas. Sci Rep 6:33163

Horton TW, Zerbini AN, Andriolo A, Danilewicz D, Sucunza F (2020) Multi-decadal humpback whale migratory route fidelity despite oceanographic and geomagnetic change. Front Mar Sci 7:414

IAATO (International Association of Antarctica Tour Operators) (2020) Antarctic tourism data \& statistics. https:// iaato.org/tourism-statistics (accessed 8 April 2020)

Iñiguez MA, Belgrano J, Tomsin A, de Haro C, Gribaudo C, Tossenberger V (2003) Sighting and stranding of southern right whales (Eubalaena australis) off Santa Cruz, Patagonia Argentina (1986-2003). Paper SC/55/BRG8 presented to the IWC Scientific Committee, June 2003

IWC (International Whaling Commission) (2001) Report of the workshop on the comprehensive assessment of right whales: a worldwide comparison. J Cetacean Res Manag Spec Issue 2:1-60

IWC (2011) Report of the southern right whale die-off workshop, 15-18 March 2010. Puerto Madryn, Argentina. J Cetacean Res Manag 12(Suppl):365-398

IWC (2013) Report of the IWC workshop on the assessment of southern right whales. J Cetacean Res Manag 14(Suppl): 439-462

IWC (2016) Report of the second workshop on mortality of southern right whales (Eubalaena australis). J Cetacean Res Manag 17(Suppl):585-598

Joiris CR, Humphries GRW, D'Hert D, Lafontaine R, Robert H, Beudels-Jamar RC (2015) Major hotspots detected along the Scotia Ridge in autumn for southern right whales Eubalaena australis, Antarctic fur seals Arctocephalus gazella and Antarctic prions Pachyptila desolata. Adv Polar Sci 26:282-291

Korb RE, Whitehouse M (2004) Contrasting primary production regimes around South Georgia, Southern Ocean: large blooms versus high nutrient, low chlorophyll waters. Deep Sea Res I 51:721-738

Kraus SD, Moore KE, Price CA, Crone MJ, Watkins WA, Winn HE, Prestcott JH (1986) The use of photographs to identify individual North Atlantic right whales (Eubalaena glacialis). Rep Int Whal Comm Spec Issue 10:145-151

Krützen M, Barré LM, Möller, LM, Heithaus MR, Simms C, Sherwin WB (2002) A biopsy system for small cetaceans: darting success and wound healing in Tursiops spp. Mar Mamm Sci 18:863-878

* Lambertsen RH (1987) A biopsy system for large whales and its use for cytogenetics. J Mammal 68:443-445

Leaper R, Cooke J, Trathan P, Reid K, Rowntree V, Payne R (2006) Global climate drives southern right whale (Eubalaena australis) population dynamics. Biol Lett 2: 289-292

Marón CF, Beltramino L, Di Martino M, Chirife A and others (2015) Increased wounding of southern right whale (Eubalaena australis) calves by kelp gulls (Larus dominicanus) at Península Valdés, Argentina. PLOS ONE 10: $\mathrm{e} 0139291$
Mate B, Best PB, Lagerquist BA, Winsor MH (2011) Coastal, offshore, and migratory movements of South African right whales revealed by satellite telemetry. Mar Mamm Sci 27:455-476

Matthews LH (1932) Lobster krill. Discov Rep 5:467-484

Matthews LH (1938) Notes on the southern right whale Eubalaena australis. Discov Rep 17:169-182

Matthews LP, McCordic JA, Parks SE (2014) Remote acoustic monitoring of North Atlantic right whales (Eubalaena glacialis) reveals seasonal and diel variations in acoustic behavior. PLOS ONE 9:e91367

McDonald MA (2004) DiFAR hydrophone usage in whale research. Can Acoust 32:155-160

* Mellinger DK, Nieukirk SL, Matsumoto H, Heimlich SL and others (2007) Seasonal occurrence of North Atlantic right whale (Eubalaena glacialis) vocalizations at two sites on the Scotian Shelf. Mar Mamm Sci 23:856-867

* Miller BS, Barlow J, Calderan S, Collins K and others (2015) Validating the reliability of passive acoustic localisation: a novel method for encountering rare and remote Antarctic blue whales. Endang Species Res 26:257-269

* Miller BS, Calderan S, Gillespie D, Weatherup G, Leaper R, Collins K, Double MC (2016) Software for real-time localization of baleen whale calls using directional sonobuoys: a case study on Antarctic blue whales. J Acoust Soc Am 139:EL83

* Miller CA, Best PB, Perryman WL, Baumgartner MF, Moore MJ (2012) Body shape changes associated with reproductive status, nutritive condition and growth in right whales Eubalaena glacialis and E. australis. Mar Ecol Prog Ser 459:135-156

*Moore MJ, Berrow SD, Jensen BA, Carr P and others (1999) Relative abundance of large whales around South Georgia (1979-1998). Mar Mamm Sci 15:1287-1302

Munger LM, Wiggins SM, Moore SE, Hildebrand JA (2008) North Pacific right whale (Eubalaena japonica) seasonal and diel calling patterns from long-term acoustic recordings in the southeastern Bering Sea, 2000-2006. Mar Mamm Sci 24:795-814

*Murphy EJ, Trathan PN, Watkins JL, Reid K and others (2007) Climatically driven fluctuations in Southern Ocean ecosystems. Proc R Soc B 274:3057-3067

$\mathrm{O}^{\prime}$ Connell TC, Hedges REM, Healey MA, Simpson AHRW (2001) Isotopic comparison of hair, nail and bone: modern analyses. J Archaeol Sci 28:1247-1255

* Parks SE, Searby A, Célérier A, Johnson MP, Nowacek DP, Tyack PL (2011) Sound production behaviour of individual North Atlantic right whales: implications for passive acoustic monitoring. Endang Species Res 15:63-76

Patenaude NJ, Baker CS (2001) Population status and habitat use of southern right whales in the sub-Antarctic Auckland Islands of New Zealand. J Cetacean Res Manag Spec Issue 2:111-116

Payne R (1986) Long term behavioral studies of the southern right whale (Eubalaena australis). Rep Int Whal Comm Spec Issue 10:161-168

Payne R, Brazier O, Dorsey EM, Perkins JS, Rowntree VJ, Titus A (1983) External features in southern right whales (Eubalaena australis) and their use in identifying individuals. In: Payne R (ed) Communication and behavior of whales. Westview Press, Boulder, CO, p 371-445

Pettis HM, Rolland RM, Hamilton PK, Brault S, Knowlton AR, Kraus SD (2004) Visual health assessment of North Atlantic right whales (Eubalaena glacialis) using photographs. Can J Zool 82:8-19 
Reeves RR, Smith TD (2006) A Taxonomy of world whaling: operations, eras and data sources. In: Estes JA, DeMaster DP, Doak DF, Williams TM, Brownell RL Jr (eds) Whales, whaling and ocean ecosystems. University of California, Berkeley, CA, p 82-101

Reid K, Brierley AS, Nevitt GA (2000) An initial examination of relationships between the distribution of whales and Antarctic krill Euphausia superba at South Georgia. J Cetacean Res Manag 2:143-149

Reid WDK, Wigham BD, McGill RAR, Polunin NVC (2012) Elucidating trophic pathways in benthic deep-sea assemblages of the Mid-Atlantic ridge north and south of the Charlie-Gibbs Fracture Zone. Mar Ecol Prog Ser 463: 89-103

Reilly S, Hedley S, Borberg J, Hewitt R, Thiele D, Watkins J, Naganobu $M$ (2004) Biomass and energy transfer to baleen whales in the South Atlantic sector of the Southern Ocean. Deep Sea Res II 51:1397-1409

Richardson J, Wood AG, Neil A, Nowacek DP, Moore M (2012) Changes in distribution, relative abundance and species composition of large whales around South Georgia from opportunistic sightings: 1992 to 2011. Endang Species Res 19:149-156

Rolland RM, Schick RS, Pettis HM, Knowlton AR, Hamilton PK, Clark JS, Kraus SD (2016) Health of North Atlantic right whales Eubalaena glacialis over three decades: from individual health to demographic and population health trends. Mar Ecol Prog Ser 542:265-282

Rossi-Santos MR, Baracho C, Cipolotti S, Marcovaldi E (2007) Cetacean sightings near South Georgia islands, South Atlantic Ocean. Polar Biol 31:63-68

Rowntree VJ, Payne RS, Schell DM (2001) Changing patterns of habitat use by southern right whales (Eubalaena australis) on their nursery ground at Península Valdés, Argentina, and in their long-range movements. J Cetacean Res Manag Spec Issue 2:133-143

Rowntree V, Valenzuela LO, Franco Fraguas P, Seger J (2008) Foraging behaviour of southern right whales (Eubalaena australis) inferred from variation of carbon stable isotope ratios in their baleen. Paper SC/60/ BRG23 presented to the IWC Scientific Committee, June 2008

Saunders RA, Hill SL, Tarling GA, Murphy EJ (2019) Myctophid fish (family Myctophidae) are central consumers in the food web of the Scotia Sea (Southern Ocean). Front Mar Sci 6:530

Seyboth E, Groch KR, Dalla Rosa L, Reid K, Flores PAC, Secchi ER (2016) Southern right whale (Eubalaena australis) reproductive success is influenced by krill (Euphausia superba) density and climate. Sci Rep 6:28205

Širović A, Hildebrand J, Thiele D (2006) Baleen whale spatial patterns in the Scotia Sea during January and February 2003. J Cetacean Res Manag 8:161-171

Širović A, Johnson SC, Roche LK, Varga LM, Wiggins SM, Hildebrand JA (2015) North Pacific right whales (Eubalaena japonica) recorded in the northeastern Pacific Ocean in 2013. Mar Mamm Sci 31:800-807

Smith TD, Reeves RR, Josephson EA, Lund JN (2012) Spatial and seasonal distribution of American whaling and whales in the age of sail. PLOS ONE 7:e34905

Soldevilla MS, Rice AN, Clark CW, Garrison LP (2014) Passive acoustic monitoring on the North Atlantic right whale calving grounds. Endang Species Res 25:115-140

Staniland IJ, Morton A, Robinson SK, Malone D, Forcada J (2011) Foraging behaviour in two Antarctic fur seal colonies with differing population recoveries. Mar Ecol Prog Ser 434:183-196

Tarling GA, Ward P, Atkinson A, Collins MA, Murphy EJ (2012) DISCOVERY 2010: Spatial and temporal variability in a dynamic polar ecosystem. Deep Sea Res II 59-60: $1-13$

Tønnessen JN, Johnsen AO (1982) The history of modern whaling. University of California Press, Berkeley, CA

* Tormosov DD, Mikhaliev YA, Best PB, Zemsky VA, Sekiguchi K, Brownell RL Jr (1998) Soviet catches of southern right whales Eubalaena australis, 1951-1971. Biological data and conservation implications. Biol Conserv 86:185-197

Torres LG, Smith TD, Sutton P, MacDiarmid A, Bannister J, Miyashita T (2013) From exploitation to conservation: habitat models using whaling data predict distribution patterns and threat exposure of an endangered whale. Divers Distrib 19:1138-1152

Townsend CH (1935) The distribution of certain whales as shown by logbook records of American whaleships. Zoologica (NY) 19:1-50

Trathan PN, Croxall JP (2004) Marine predators at South Georgia: an overview of recent bio-logging studies. Mem Natl Inst Polar Res Spec Issue 58:118-132

*Valenzuela LO, Sironi M, Rowntree VJ, Seger J (2009) Isotopic and genetic evidence for culturally inherited site fidelity to feeding grounds in southern right whales (Eubalaena australis). Mol Ecol 18:782-791

*Valenzuela LO, Rowntree VJ, Sironi M, Seger J (2018) Stable isotopes $\left(\delta^{15} \mathrm{~N}, \delta^{18} \mathrm{C}, \delta^{34} \mathrm{~S}\right)$ in skin reveal diverse food sources used by southern right whales Eubalaena australis. Mar Ecol Prog Ser 603:243-255

Wade PR, Kennedy A, LeDuc R, Barlow J and others (2011) The world's smallest whale population? Biol Lett 7:83-85

*Webster TA, Dawson SM, Rayment WJ, Parks SE, Van Parijs SM (2016) Quantitative analysis of the acoustic repertoire of southern right whales in New Zealand. J Acoust Soc Am 140:322-333

Whitehouse MJ, Priddle J, Brandon MA, Swanson C (1999) A comparison of chlorophyll/nutrient dynamics at two survey sites near South Georgia, and the potential role of planktonic nitrogen recycled by land-based predators. Limnol Oceanogr 44:1498-1508

* Zerbini AN, Andriolo A, Heide-Jorgensen MP, Pizzorno JL and others (2006) Satellite-monitored movements of humpback whales Megaptera novaeangliae in the southwest Atlantic Ocean. Mar Ecol Prog Ser 313:295-304

Zerbini AN, Andriolo A, Heide-Jørgensen MP, Moreira S and others (2011) Migration and summer destinations of humpback whales (Megaptera novaeangliae) in the western South Atlantic Ocean. J Cetacean Res Manag Spec Issue 3:113-118

Zerbini AN, Rosenbaum H, Mendez M, Sucunza F and others (2016) Tracking southern right whales through the southwest Atlantic: an update on movements, migratory routes and feeding grounds. Paper SC/66b/BRG26 presented to the IWC Scientific Committee, June 2016

Zerbini AN, Ajó AF, Andriolo A, Clapham PJ and others (2018) Satellite tracking of southern right whales (Eubalaena australis) from Golfo San Matías, Rio Negro Province, Argentina. Paper SC/67b/CMP17 presented to the IWC Scientific Committee, May 2018

Zerbini AN, Adams G, Best J, Clapham PJ, Jackson JA, Punt AE (2019) Assessing the recovery of an Antarctic krill predator from historical exploitation. R Soc Open Sci 6: 190368 